\title{
An attempt to Stimulate lipids for Biodiesel Production from locally Isolated Microalgae in Iraq
}

\author{
Fikrat M. Hassan ${ }^{*} \quad$ Ibtsam F. Aljbory ${ }^{* *} \quad$ Thaer I. Kassim **** \\ Received 17, June, 2012 \\ Accepted 1, July, 2012
}

\begin{abstract}
:
Two locally isolated microalgae (Chlorella vulgaris Bejerinck and Nitzschia palea (Kützing) W. Smith) were used in the current study to test their ability to production biodiesel through stimulated in different nitrogen concentration treatments $(0,2,4,8$ gll ), and effect of nitrogen concentration on the quantity of primary product (carbohydrate, protein ), also the quantity and quality of lipid. The results revealed that starvation of nitrogen led to high lipid yielding, in $C$. vulgaris and $N$. palea the lipid content increased from $6.6 \%$ to $40 \%$ and $40 \%$ to $60 \%$ of dry weight (DW) respectively.Also in C. vulgaris, the highest carbohydrate was $23 \%$ of DW from zero nitrate medium and the highest protein was $50 \%$ of DW in the treatment $8 \mathrm{gll}$. While in $N$. palea the highest carbohydrate was $25 \%$ of DW in the treatment $4 \mathrm{gl}$, and the highest protein was $15 \%$ of DW in $8 \mathrm{gll}$ treatment.
\end{abstract}

Key words: Microalgae, lipids, Stearic acid, Oleic acid, Biodiesel

\section{Introduction:}

Microalgae are photosynthetic organisms that have the ability to fix $\mathrm{CO} 2$, so the light energy will transform to chemical energy inside the alga's cell [1]. They may be used in different ways, such as purification of waste water under either autotrophic or mixotrophic conditions [2] extractions of high added value food such as polyunsaturated fatty acids [3] and pigments such as $\beta$-carotene and astaxanthin, also pharmaceutical products, in addition to play an important role in the aquaculture business as food for aquaculture and biofuel production which got a great attention in the present century [4,5] Lipid can be produced and extracted from microalgae cells. This lipid can be used in transformation to biofuel especially biodiesel [6] This transformation will be reducing the pollution of petroleum, natural gas, coal, hydro, and nuclear energy [7] which are major source of green house gases emissions (GHG). These emissions are affecting the environment and cause great damages [8] Because of the minifying petroleum advance and increasing environmental worry with the increasing in fossil energy, renewable and cleaner biofuel from microalgae have appeared and got a big attention in recent years [9]The best candidates for fuel production are Microalgae because of: there advantages of higher photosynthetic efficiency, higher biomass production, faster growth compared to other energy crops, they can grow practically anywhere, use far less water than traditional oil seed crops, they have no competition with food crops, and they are the only feed stock that can replace transportation fuels [10]Felizardo et al[11] study showed that biodiesel can be made from any oil or lipid source such as vegetable oils and animal fats. Oil contains a glycerol molecule bonded to three fatty acid chains, this structure is called a triglyceride, and it is the major

College of Science, University of Baghdad, Baghdad-Iraq.

${ }^{* *}$ Market Research and Consumer protection Center, University of Baghdad, Baghdad-Iraq.

${ }^{* * *}$ Genetic Engineering and Biotechnology-University of Baghdad, Baghdad-Iraq 
component of the oil. Biodiesel fuel has received considerable attention in recent years, as it is a biodegradable, renewable and non-toxic fuel. It contributes no net carbon dioxide or sulfur to the atmosphere and emits less gaseous pollutants than normal diesel [4]. $\mathrm{Hu}$ et al[12] study showed that there are several ways to make biodiesel, and the most common way is transesterification and biodiesel can be used directly with diesel fuel in diesel engine.Hundreds of microalgae strains capable of producing high content of lipid have been screened and their lipid production metabolisms have been characterized and reported for biodiesel $[6,13]$ This study is the first attempt to isolate locally microalgae from Iraqi aquatic systems and to stimulate the production of biodiesel from these isolates.

\section{Material and Methods:}

Two species of algae were isolated from ponds and artificial canal of University of Baghdad in Al-Jadriya campus, also from Tigris River at AlRasheed area, Baghdad-Iraq. The studied algae are Chlorella vulgaris Bejerinck and Nitzschia palea (Kützing) W. Smith. Modified Chu-10 [14] was used for the algal growth (Table 1). Serial dilution method and streaking on plate agar techniques were used for algae isolation and purification in this study. For algae cultivation, $10 \mathrm{ml}$ of isolated culture was added to a flask containing $100 \mathrm{ml}$ of Chu-10 media and incubated for 14 days, then transported to $1000 \mathrm{ml}$ of media and incubated for 14 days; finally the growth was transported to glass pools $5 \mathrm{~L}$ for mass culture. The growth curve was determined for the two studied algae. Cell growth was measured by determining the optical density (O.P) daily. Optical density $(540 \mathrm{~nm})$ was measured by using spectrophotometer UV-VIS (540 nm).
All measurements of the study were triplicates.

The growth rate $(\mathrm{K})$ and doubling time (G) were obtained according to the following equation:

$$
\begin{aligned}
& \mathrm{K}=\frac{\left(\log \mathrm{OD}_{\mathrm{t}}-\log \mathrm{OD}_{0}\right.}{\mathrm{t}} * 3.322[15] \\
& \mathrm{G}=\frac{0.301}{\mathrm{~K}} \quad[16]
\end{aligned}
$$

T: time (day)

$\mathrm{OD}_{\mathrm{t}}$ : Optical density after $(\mathrm{t})$ day

$\mathrm{OD}_{\mathrm{o}}$ : Optical density at beginning of the experiment zero time

\section{Experiment design:}

Different concentrations of nitrogen were used in the current study, to stimulate the isolated algae for production lipid that can be used as biodiesel. Nitrate was used as a source of nitrogen in media $\left(\mathrm{NaNO}_{3}\right)$ by $8 \mathrm{~g} / 1$ and considered as control treatment in the study; also other three concentrations of nitrate $(4,2$, zero $g / 1)$ were used as treatments. These treatments represent a gradual reduction in concentration of nitrogen (Nitrate) used in the media up to remove completely nitrate from the culture's media.Microalgae had been harvested at the beginning of the stationary phase. Each culture of microalgae was centrifuged in the cooled centrifuge at $3000 \mathrm{rpm}$ for 15 min, supernatant removed but organic precipitate had been washed with distilled water, and then dried at $45 \mathrm{C}^{\circ}$ for two days. The dry weight was collected for extraction.

\section{Lipid extraction and analysis:}

A $1 \mathrm{~g}$ of dry weight had been put in thimble and carried to specific cylinder in the soxhlet. A $200 \mathrm{ml}$ of solvent (mixture from methanol and hexane 
1:1) had been put in the flask after which the process took three-four hours; the solvents color in the cylinder will change from green to colorless. The extracted sample was dried by rotary evaporator at $40 \mathrm{C}^{\circ}$ for few minutes. The result was poured out to a plate and left in room temperature $25 \mathrm{C}^{\circ}$ overnight, then transferred to test tube until analysis [17] Samples were analyzed by High Performance Liquid Chromatography (HPLC) system, model SUPELCO. The column is discovery HSC18 dimension $25 \mathrm{~cm} \mathrm{X}$ $4.6 \mathrm{~mm} \mathrm{X} 5 \mu \mathrm{m}$ injection flow 1 $\mathrm{ml} / \mathrm{min}$ at $\mathrm{UV}$.

\section{Determination of protein and carbohydrate:}

Algae samples were centrifuged by cooling centrifuge model Rotina $380 \mathrm{R}$ for $5000 \mathrm{r} / \mathrm{min}$ for $30 \mathrm{~min}, 4 \mathrm{C}^{\circ}$. The supernatant was collected and the protein determined according to Bradford method [18] and the carbohydrate according to phenol sulphuric acid method [19]

\section{Statistical analyses}

Complete Randomized Design (C.R.D.) was used as an experimental design. Data were analyzed by using statistical analysis system- SAS [20] to study the effect of different concentration factors on the production of lipid. Least significant difference (LSD) was used to compare the significant difference between means at $\mathrm{P} \leq 0.05$.

\section{Results and discussion:}

Two isolated algae were obtained successfully, and they were identified according to Prescott [21] and Hustedt [22]
Class: Chlorophyceae

Order: Chlorococcales

Family: Chlorococcaceae

Chlorella vulgaris Bejerinck

Class: Bacillariophyceae

Order: Pennales

Family: Bacillariaceae

Nitzschia palea (Kützing) W. Smith

Different growth was observed for both isolated algae in the treatments, and the harvesting time was also different among the treatments. Figure 1 illustrates the effect of different nitrogen concentrations on $C$. vulgaris biomass growth, figs. 1( $a$ and $b$ ) show a noticeable difference between treatment $4 \mathrm{~g} / \mathrm{l}$ and control, while there were different manner in two other treatments (figs. $1 \mathrm{c}$ and $\mathrm{d}$ ), but there were no significant differences among treatments (table 2). The biomass growth of $C$. vulgaris entered a stationary phase in different days among treatments. The stationary phase was identified as day 12, 8, 6 and 4 in treatments $8,4,2$ and zero $\mathrm{g} / \mathrm{l}$ nitrogen respectively. The $\mathrm{K}$ value increased from $0.1-0.19$ for the treatments $8 \mathrm{~g} / \mathrm{l}$ and zero $\mathrm{g} / \mathrm{l}$ respectively (fig. 1). The shortest doubling time was 1.5 days in treatment zero $\mathrm{g} / \mathrm{l}$ while the longest was 2.7 days in control $(8 \mathrm{~g} / \mathrm{l})$, a significant difference was recorded between zero treatment and control, while there were no significant differences among other treatments with control (table 3). The stationary phase was identified as day $10,8,6,5$ in treatments 8, 4, 2 and zero $\mathrm{g} / \mathrm{l}$ (fig. 2 ). The $\mathrm{K}$ value of $N$. palea increased from 0.06 at control treatment to 0.26 at treatment zero $\mathrm{g} / \mathrm{l}$. The shortest doubling time (1.1 days) and highest $\mathrm{K}$ value occurred at treatment zero $\mathrm{g} / \mathrm{l}$, while the longest doubling time (5 days) and lowest $\mathrm{K}$ value recorded at control $(8 \mathrm{~g} / \mathrm{l})$. The harvesting biomasses of both isolated algae were done in stationary phase for lipid, 
protein and carbohydrate analysis. Lipid content of algae is an important parameter that determines the economy of biodiesel production from algae [23]The lipid content for C. vulgaris ranged from $6.5 \%$ at control to $40 \%$ at zero treatment, and statistically there are significant differences among treatments except between control and treatment $4 \mathrm{~g} / \mathrm{l}$ where no significant differences (table 3). The same trend was shown for $N$. palea. The lipid contents for $C$. vulgaris and $N$. palea increased from $6.6 \%$ to $40 \%$ and $40 \%$ to $60 \%$ of dry weight respectively, when it was extracted in early stationary phase. The present study revealed that concentration of nitrate is significantly affecting lipid content of both microalgae specially at zero concentration which achieved higher lipid content than control nitrate media and other treatments. Alga lipid content usually increases at nitrogen starvation, due to lipid-synthesizing enzymes are less affected by disorganization than carbohydrate synthesizing enzymes, thus, the major proportion of carbon can be bound in lipids [5,6] These results were also reported in the other literatures $[10,24,25,26,27]$ Shen et al[24] revealed that lipid yields of heterotrophic Chlorella protothecoides increased from 4 to $5.89 \%$ of dry weight, so the studied alga produced more lipids in low-nitrogenconcentration media. Another study [27] showed that nitrogen treatments increased the lipid ratio of alga Nannochloropsis oculata from $7 \%$ at $0.3 \mathrm{gll} \mathrm{NaNO3}$ to $16 \%$ at $0.075 \mathrm{gll}$ NaNO3.Miao and $\mathrm{Wu}$ [10] noticed in their study on alga $C$. protothecoides that the protein level decreased to $10.28 \%$ and the lipid level increased to $55.20 \%$ during heterotrophic growth. This change in growth parameters was also noticed in the present study that may be the limitation of nitrogen concentration in media growth limited protein biosynthesis thus increasing lipid and carbohydrates were recorded [26,27,28] Oleic acid content (\%) showed only significant differences between control and zero treatment, while other treatments have no significant differences with control for C. vulgaris. A significant difference in oleic contents for $N$. palea was recorded between treatments (2, zero) and control (table 5). The results of Stearic acid content in both studied microalgae showed the same trend. Higher content was recorded at zero treatment, while lower content at control. There are significant differences among treatments except between control and treatment $4 \mathrm{~g} / \mathrm{l}$ were no significant differences (table 6). Fatty acids (Stearic, Oleic) increased in studied treatments $(8,4$, 2and 0 ) from $0.7 \%$ to $26 \%, 0.05 \%$ to $6 \%$ and $1.5 \%$ to $34.5 \%, 2 \%$ to $15 \%$ of total lipid respectively (figures 4 and 6 ). The present study results were in agreements with those reported by Afify et al. [29]. The Stearic acid (18:0) is considered as the most common fatty acid in biodiesel that is present in this study encourage to use the studied algae to produce biodiesel in addition to increasing of Oleic acid (18:1 $\Delta 9)$. Carbohydrate content of $C$. vulgaris ranged from $16.5 \%$ at control to $25 \%$ of dry weight at zero treatment. A Significant difference was recorded only between zero treatment and other treatments. While, the carbohydrate content of $N$. palea ranged between $20 \%$ at treatments (control and zero) to $25 \%$ at treatment $4 \mathrm{~g} / \mathrm{l}$, and there was a significant difference between treatment $4 \mathrm{~g} / \mathrm{l}$ and other treatments (table 7).Protein content of both studied microalgae decreased sharply among treatments in contrast with control treatment. The protein content was higher in $C$. vulgaris than in $N$. palea. Significant differences were 
recorded among treatments at both studied microalgae (table 8). Carbohydrate and protein concentrations showed differences in their concentrations at studied treatments (figures 3 and 5).

\section{Conclusions:}

The different concentrations of nitrogen influenced the lipid, protein and carbohydrate contents of the studied microalgae, and affecting strongly on the lipids productivity of C. vulgaris and $N$. palea. Nitrogen also affects the qualitative and quantitative analysis of fatty acids and gives very high values of Stearic acid and Oleic acid that were extracted from the microalgae.

Table ( 1 ) The components concentration of modified Chu-10 medium and the concentration of each component

\begin{tabular}{|c|c|c|}
\hline $\begin{array}{c}\text { Number of stock } \\
\text { solution }\end{array}$ & $\begin{array}{c}\text { Chemical formula of each } \\
\text { salt }\end{array}$ & $\begin{array}{c}\text { Concentration } \\
\mathrm{g} / \mathrm{l}\end{array}$ \\
\hline 1 & $\mathrm{MgSO}_{4} \cdot 7 \mathrm{H}_{2} \mathrm{O}$ & 10 \\
\hline 2 & $\mathrm{~K}_{2} \mathrm{HPO}_{4}$ & 4 \\
\hline 3 & $\mathrm{NaNO}_{3}$ & 8 \\
$\mathrm{CaCl}_{2}$ & 16 \\
\hline 4 & $\mathrm{FeCl}_{3}$ & 0.32 \\
\hline 5 & $\mathrm{EDTA} \mathrm{Na}$ & 4 \\
\hline 6 & $\mathrm{NaCl}_{2}$ & 30 \\
\hline 7 & $\mathrm{Na}_{2} \mathrm{CO}_{3}$ & 8 \\
\hline & $\mathrm{MnCl}_{2} \cdot 4 \mathrm{H}_{2} \mathrm{O}$ & 0.02 \\
& $\left(\mathrm{NH}_{4}\right) \mathrm{CMo}_{7} \mathrm{O}_{24} .4 \mathrm{H}_{2} \mathrm{O}$ & 0.028 \\
\hline 8 & $\mathrm{ZnSO}_{4} \cdot 7 \mathrm{H}_{2} \mathrm{O}$ & 0.224 \\
& $\mathrm{CuSO}_{4} \cdot 5 \mathrm{H}_{2} \mathrm{O}$ & 0.08 \\
& $\mathrm{COCl}_{2} \cdot 6 \mathrm{H}_{2} \mathrm{O}$ & 0.004 \\
& $\mathrm{H}_{3} \mathrm{BO}_{3}$ & 0.288 \\
\hline 9 & $\mathrm{Na}_{2} \mathrm{SiO}_{3}$ & 5.7 \\
\hline
\end{tabular}

Table2. Effect of different concentrations of nitrogen in the growth medium on growth rate (mean \pm SE) of studied microalgae.

\begin{tabular}{|c|c|c|c|}
\hline $\begin{array}{c}\text { Concentration } \\
(\mathrm{g} / \mathrm{l})\end{array}$ & \multicolumn{2}{|c|}{ Studied microalgae } & \multirow{2}{*}{ LSD value } \\
\cline { 2 - 3 } & C. vulgaris & N. palea & \\
\hline Control (8) & $0.11 \pm 0.04 \mathrm{~A}$ & $0.06 \pm 0.01 \mathrm{~B}$ & $0.08 \mathrm{NS}$ \\
\hline$(4)$ & $0.14 \pm 0.07 \mathrm{~A}$ & $0.11 \pm 0.05 \mathrm{~B}$ & $0.06 \mathrm{NS}$ \\
\hline$(2)$ & $0.15 \pm 0.07 \mathrm{~A}$ & $0.17 \pm 0.07 \mathrm{AB}$ & $0.06 \mathrm{NS}$ \\
\hline Zero & $0.19 \pm 0.08 \mathrm{~A}$ & $0.26 \pm 0.11 \mathrm{~A}$ & $0.11 \mathrm{NS}$ \\
\hline LSD value & $0.08 \mathrm{NS}$ & $0.122 *$ & --- \\
\hline
\end{tabular}

NS: non-significant.

The same letters in the column show no statistically different $(\mathrm{P} \leq 0.05)$ 
Table 3 . Doubling time (mean $\pm \mathrm{SE}$ ) of studied microalgae at different nitrogen concentrations in the growth medium.

\begin{tabular}{|c|c|c|c|}
\hline $\begin{array}{c}\text { Concentration } \\
(\mathrm{g} / \mathrm{l})\end{array}$ & \multicolumn{2}{|c|}{ Studied microalgae } & \multirow{2}{*}{ LSD value } \\
\cline { 2 - 3 } & C. vulgaris & N. palea & \\
\hline Control $(8)$ & $2.7 \pm 0.09 \mathrm{~A}$ & $5.0 \pm 0.32 \mathrm{~A}$ & $1.47 *$ \\
\hline$(4)$ & $2.15 \pm 0.09 \mathrm{AB}$ & $2.7 \pm 0.09 \mathrm{~B}$ & $0.95 \mathrm{NS}$ \\
\hline$(2)$ & $2.0 \pm 0.08 \mathrm{AB}$ & $1.7 \pm 0.08 \mathrm{~B}$ & $0.69 \mathrm{NS}$ \\
\hline Zero & $1.5 \pm 0.08 \mathrm{~B}$ & $1.0 \pm 0.02 \mathrm{~B}$ & $0.71 \mathrm{NS}$ \\
\hline LSD value & $0.72 *$ & $1.49 *$ & --- \\
\hline
\end{tabular}

$*(\mathrm{P}<0.05), \mathrm{NS}$ : non-significant.

The same letters in the column show no statistically different $(\mathrm{P} \leq 0.05)$

Table4. Effect of different concentrations of nitrogen in the growth medium on total lipid (\%) content (mean \pm SE) of studied microalgae

\begin{tabular}{|c|c|c|c|}
\hline $\begin{array}{c}\text { Concentration } \\
(\mathrm{g} / \mathrm{l})\end{array}$ & \multicolumn{2}{|c|}{ Studied microalgae } & \multirow{2}{*}{ LSD value } \\
\cline { 2 - 3 } & C. vulgaris & N. palea & \\
\hline Control $(8)$ & $6.5 \pm 0.52 \mathrm{C}$ & $40 \pm 2.58 \mathrm{C}$ & 6.73 \\
\hline$(4)$ & $9.0 \pm 0.86 \mathrm{C}$ & $45 \pm 2.84 \mathrm{C}$ & 8.02 \\
\hline$(2)$ & $25 \pm 1.53 \mathrm{~B}$ & $50 \pm 2.92 \mathrm{~B}$ & 6.39 \\
\hline Zero & $40 \pm 2.07 \mathrm{~A}$ & $60 \pm 3.66 \mathrm{~A}$ & 6.07 \\
\hline LSD value & 8.38 & 6.55 & --- \\
\hline
\end{tabular}

The same letters in the column show no statistically different $(\mathrm{P} \leq 0.05)$

Table5. Effect of different concentrations of nitrogen in the growth medium on Oleic acid $(\%)$ content (mean \pm SE) of studied microalgae

\begin{tabular}{|c|c|c|c|}
\hline $\begin{array}{c}\text { Concentration } \\
(\mathrm{g} / \mathrm{l})\end{array}$ & \multicolumn{2}{|c|}{ Studied microalgae } & \multirow{2}{*}{ LSD value } \\
\cline { 2 - 3 } & C. vulgaris & N. palea & \\
\hline Control $(8)$ & $0.05 \pm 0.01 \mathrm{~B}$ & $2 \pm 0.03 \mathrm{C}$ & 0.09 \\
\hline$(4)$ & $0.4 \pm 0.03 \mathrm{~B}$ & $5 \pm 0.07 \mathrm{BC}$ & 1.04 \\
\hline$(2)$ & $0.5 \pm 0.07 \mathrm{~B}$ & $8 \pm 0.13 \mathrm{~B}$ & 2.66 \\
\hline Zero & $6.0 \pm 0.11 \mathrm{~A}$ & $15 \pm 0.74 \mathrm{~A}$ & 5.82 \\
\hline LSD value & $2.17 *$ & $5.38 *$ & --- \\
\hline
\end{tabular}

The same letters in the column show no statistically different $(\mathrm{P} \leq 0.05)$

Table6. Effect of different concentrations of nitrogen in the growth medium on Stearic acid (\%) content (mean \pm SE) of studied microalgae

\begin{tabular}{|c|c|c|c|}
\hline \multirow{2}{*}{$\begin{array}{c}\text { Concentration } \\
(\mathrm{g} / \mathrm{l})\end{array}$} & \multicolumn{2}{|c|}{ Studied microalgae } & \multirow{2}{*}{ LSD value } \\
\cline { 2 - 3 } & C. vulgaris & N. palea & \\
\hline Control $(8)$ & $0.7 \pm 0.09 \mathrm{C}$ & $1.5 \pm 0.03 \mathrm{C}$ & 0.36 \\
\hline$(4)$ & $5.7 \pm 0.47 \mathrm{C}$ & $3.0 \pm 0.08 \mathrm{C}$ & 0.82 \\
\hline$(2)$ & $17 \pm 0.94 \mathrm{~B}$ & $15 \pm 0.90 \mathrm{~B}$ & 1.25 \\
\hline Zero & $26 \pm 1.53 \mathrm{~A}$ & $34.5 \pm 1.66 \mathrm{~A}$ & 3.77 \\
\hline LSD value & $5.92 *$ & $7.44 *$ & --- \\
\hline
\end{tabular}

The same letters in the column show no statistically different $(\mathrm{P} \leq 0.05)$ 
Table7. Effect of different concentrations of nitrogen in the growth medium on total carbohydrate contents (mean $\pm \mathrm{SE}$ ) of studied microalgae.

\begin{tabular}{|c|c|c|c|}
\hline \multirow{2}{*}{$\begin{array}{c}\text { Concentration } \\
(\mathrm{g} / \mathrm{l})\end{array}$} & \multicolumn{2}{|c|}{ Studied microalgae } & \multirow{2}{*}{ LSD value } \\
\cline { 2 - 3 } & C. vulgaris & N. palea & \\
\hline Control $(8)$ & $16.5 \pm 0.86 \mathrm{~B}$ & $20 \pm 1.04 \mathrm{~B}$ & $3.76 \mathrm{NS}$ \\
\hline$(4)$ & $19.5 \pm 0.94 \mathrm{~B}$ & $25 \pm 1.31 \mathrm{~A}$ & 3.42 \\
\hline$(2)$ & $22 \pm 1.23 \mathrm{AB}$ & $21 \pm 1.16 \mathrm{~B}$ & $3.50 \mathrm{NS}$ \\
\hline Zero & $25 \pm 1.31 \mathrm{~A}$ & $20 \pm 1.04 \mathrm{~B}$ & 3.75 \\
\hline LSD value & $4.74 *$ & $3.92 *$ & --- \\
\hline
\end{tabular}

NS: non-significant.

The same letters in the column show no statistically different $(\mathrm{P} \leq 0.05)$

Table8. Effect of different concentrations of nitrogen in the growth medium on total Protein contents (mean \pm SE) of studied microalgae.

\begin{tabular}{|c|c|c|c|}
\hline \multirow{2}{*}{$\begin{array}{c}\text { Concentration } \\
(\mathrm{g} / \mathrm{l})\end{array}$} & \multicolumn{2}{|c|}{ Studied microalgae } & \multirow{2}{*}{ LSD value } \\
\cline { 2 - 3 } & C. vulgaris & N. palea & \\
\hline Control $(8)$ & $50 \pm 2.47 \mathrm{~A}$ & $15 \pm 0.64 \mathrm{~A}$ & 6.37 \\
\hline$(4)$ & $33 \pm 1.52 \mathrm{~B}$ & $10 \pm 0.52 \mathrm{~B}$ & 5.92 \\
\hline$(2)$ & $27 \pm 1.29 \mathrm{~B}$ & $7 \pm 0.11 \mathrm{BC}$ & 5.39 \\
\hline Zero & $15 \pm 0.64 \mathrm{C}$ & $3 \pm 0.04 \mathrm{C}$ & 4.18 \\
\hline LSD value & $8.39 *$ & $4.74 *$ & --- \\
\hline
\end{tabular}

The same letters in the column show no statistically different $(\mathrm{P} \leq 0.05)$

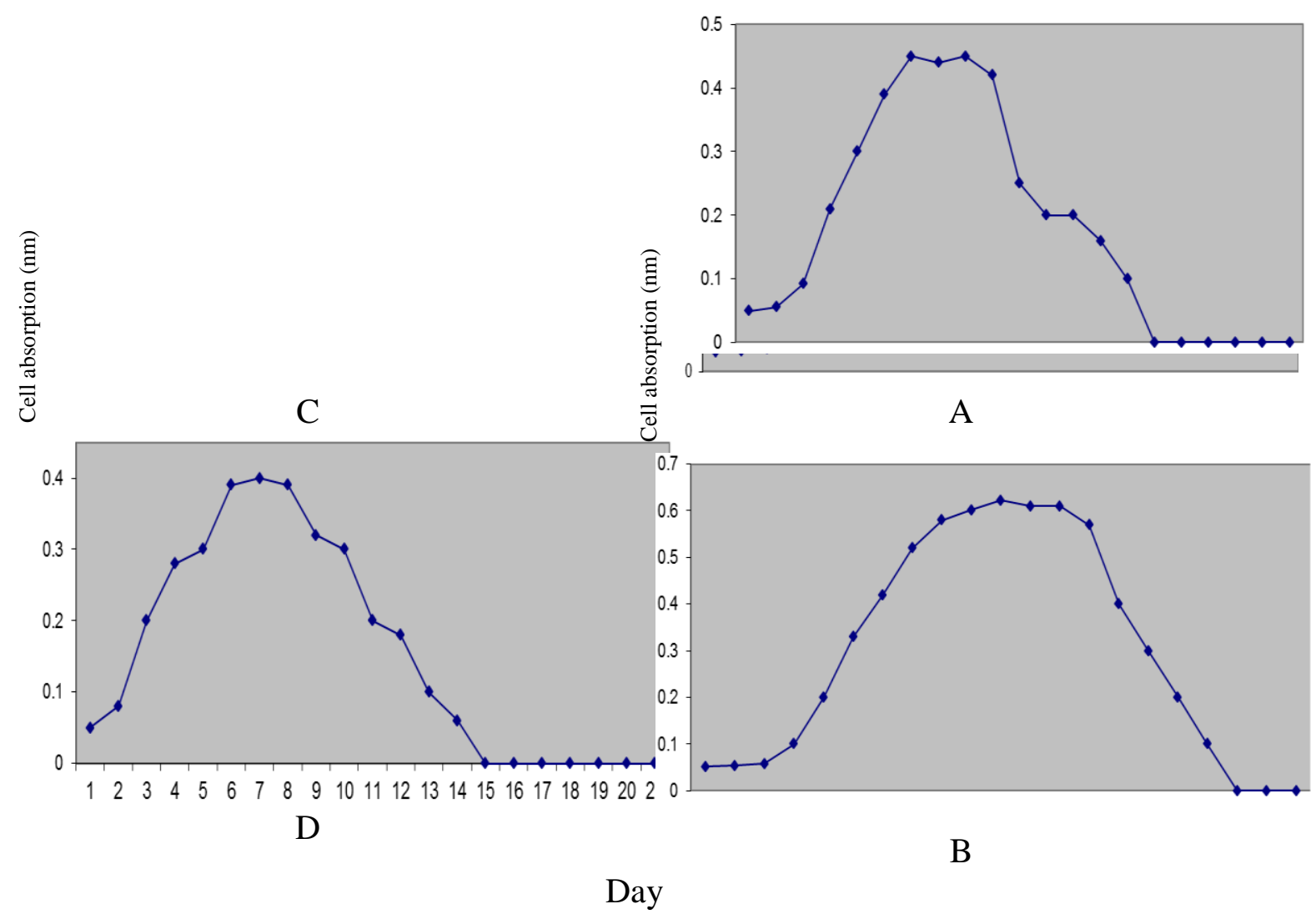

Fig. (1). Growth curve of $C$. vulgaris at different nitrate concentration ( $\mathrm{mg} / \mathrm{l})$ $a=8 ; b=4 ; c=2 ; d=z e r o$ 


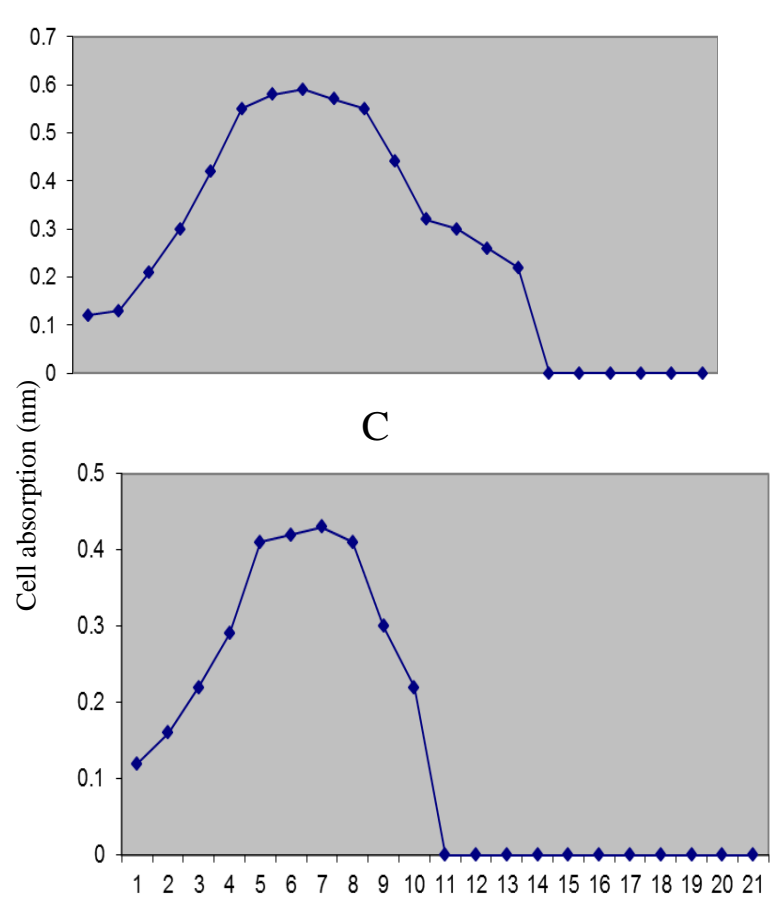

$\mathrm{D}$

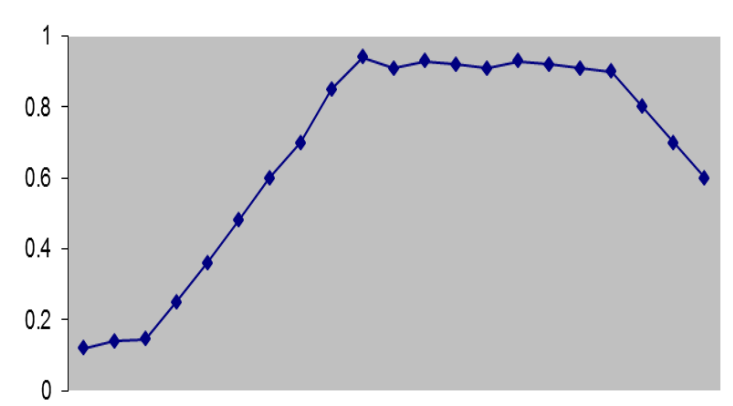

A

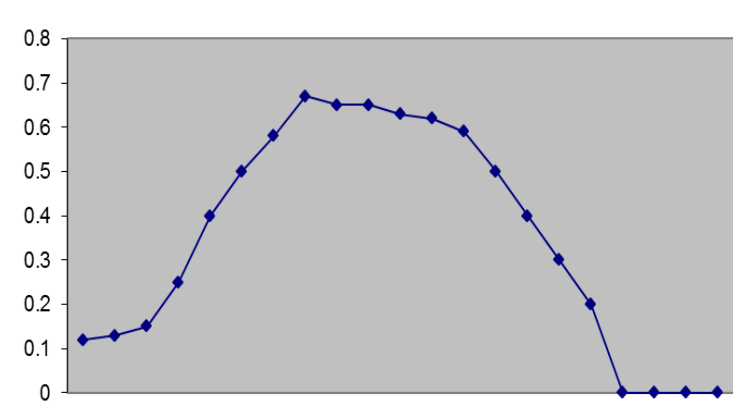

B

Day

Fig. 2. Growth curve of Nitizchia palea at different nitrate concentrations (mg/l). $a=8 ; b=4 ; c=2 ; d=$ zero

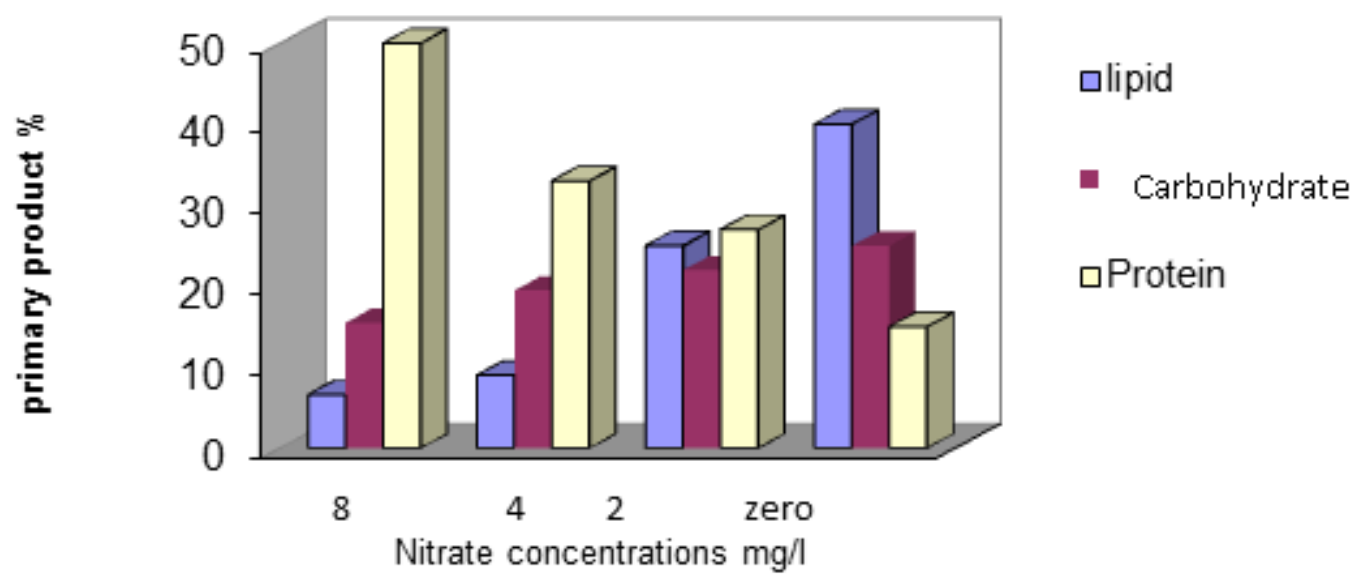

Fig. 3. Total lipid, carbohydrate and protien of C.vulgaris at variouse nitrate concentrations. 


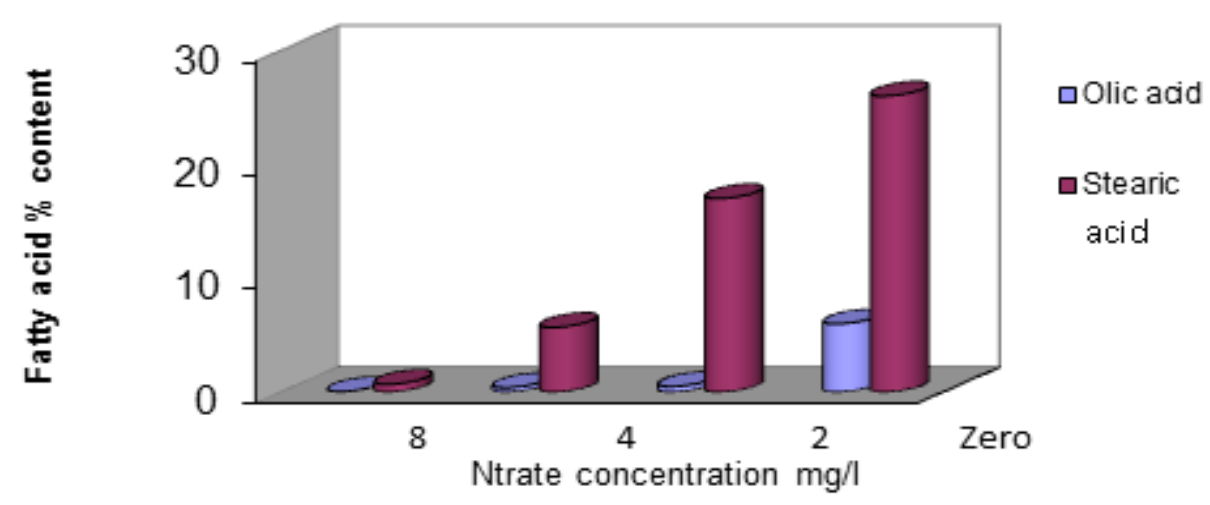

Fig. 4. Fatty acids of $C$. vulgaris at various nitrate concentrations.

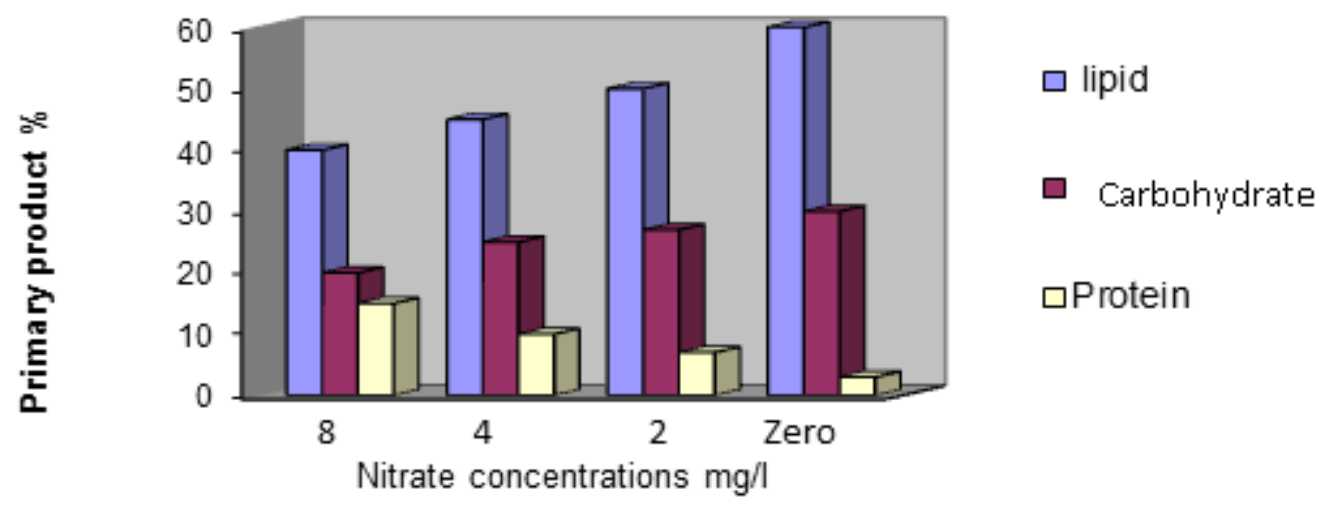

Fig. 5. Total lipid ,carbohydrate and protien of N.palea at various nitrate concentrations.

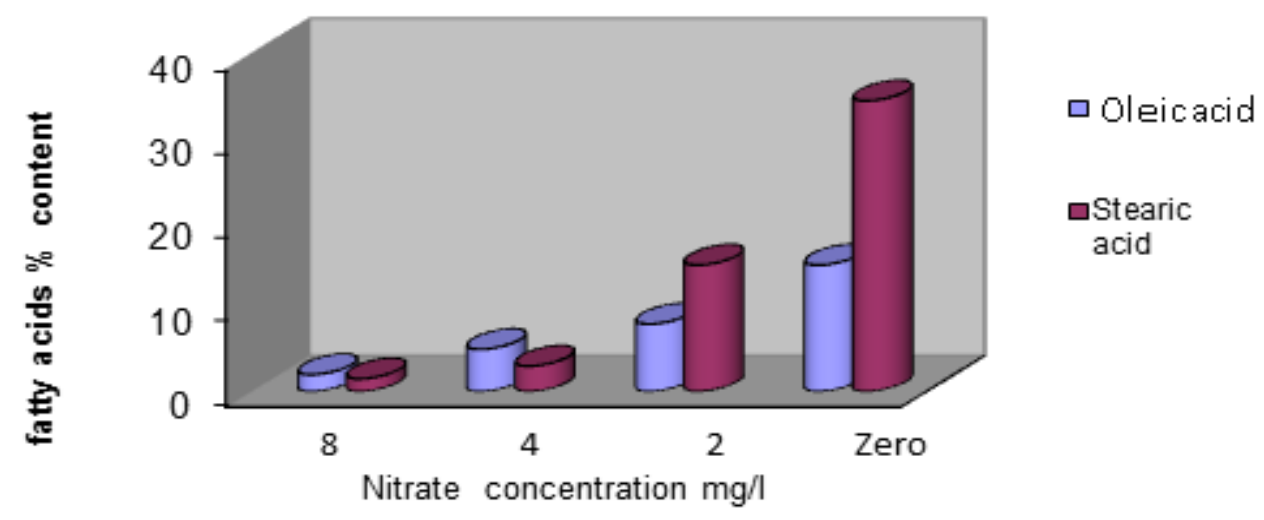

Fig. 6. Fatty acids of $N$. palea at various nitrate concentrations.

\section{References:}

1. Khan S. A, Rashmi Mir. Z. Husain, Prasad S. and Banerjee U. C. 2009. Prospects of biodiesel production from microalgae in India. Renew. Sustain. Energy Rev. 13, 23612372.

2. Munoz, R.and Guieysse, B. 2006. Algal-bacterial processes for the treatment of hazardous contaminants: A review, Water Research,. 40: 2799-2815.

3. Ward, O.P. and Singh, A. 2005. -Omega-3/6 fatty acids: alternative sources of production. Process Biochemistry. 86: 3627-3652.

4. Spolaore, P., Joannis-Cassan, C., Duran, E.and Isambert, A. 2006. 
Commercial applications of microalgae, J. Bios. Bioeng, 101: 87-96

5. Becker, W. 2004. -Microalgae in human and animal nutrition. Richmond, A., ed. Handbook of microalgal culture. Blackwell, Oxford. 312-351.

6. Chisti, Y. 2007. Biodiesel from microalgae,

Biotechnology Advances 25: 294-306.

7. Kulkarni, M. G. and Dalai,A. K. 2006.Waste cooking oil-an economical source for biodiesel: A review.Ind.EngChem.Res.45:29012913.

8. Klass, L. D. 1998. Biomass for Renewable Energy, Fuels and Chemicals. Academic Press, NewYork. pp 1-2.

9. Rodolfi L, Zittelli G C, Bassi N, Padovani G, Biondi N, Bonini G. and Tredici M R. 2009. Microalgae for oil: strain selection, induction of lipid synthesis and outdoor mass cultivation in a low-cost photobioreactor. Biotechno Bioeng, 102(1): $100-112$.

10. Miao, X.and Wu, Q. 2006 Biodiesel production from heterotrophic microalgal oil, Bioresource Technology, 97: 841846.

11. Felizardo, ,Coo,M.J.N,Raposo, I.,Mendes,J.F.,Berkemeier,R.and Bordado,J.M. 2006. Production of biodiesel from waste frying oil .Waste Manag ,26(5):487-494.

12. Hu, Q., Sommerfeld,M., Jarvis, E., Ghirardi, M., Posewitz, M., Seibert, M. and Al Darzins, 2008. Microalgal triacylglycerols as feedstocks for biofuel production: Perspectives and advances. Plant Journal. 54(4): 621-639

13. Sheehan, J., Dunahay, T., Benemann, J. and Roessler, P. 1998. Look Back at the U.S. Department of Energy's Aquatic Species
Program: Biodiesel from Algae; Close-Out Report: Size: 325 pages.

14. Kassim,T.I.;Al-Saadi,H.;and

Salman,N.A. 1999.Production of some phyto-and zooplankton and their use as live food for fish larva.Iraqi J.Agric.Proc.of $2^{\text {nd }}$ Sci.Confer.Nov.4(5):188-201.

15. Huang X.H., Li, C.L., Liu, C.W. and Zeng, D.Q. 2002a. Studies on the Ecological Factors of Oocystis borgei. J. Zhanjiang Ocean Univ. 22(3): 8-12.

16. Huang X.H., Li C.L., Liu C.W., Wang, Z.D andChen, J.J. 2002b. Studies on the $N$ and $P$ nutrient demand in Nannochloris oculata. Mar. Sci. (China). 26(8): 13-17.

17. AOAC (Association of Official Analytical Chemists) 1995. Official Methods of Analysis, $16^{\text {th }}$ Edition. AOAC International, Gaithersburg, MD.

18. Bardford, M. 1976. A rapid and sensitive method for the quantitation of microgram quantities of protein using the principle of protein dye binding. Anal. Biochem. 72:248-254.

19. Kochert, G. 1978. Carbohydrate determination by phenol-sulfuric acid method. In: Hellebust, J. A. And Craige, J. S. (eds) Handbook of Physiological and Biochemical Methods, pp. 95-97. London: Cambridge University Press.

20. SAS. 2004. SAS. Statistical Analysis System, User's Guide. Statistical. Version $7^{\text {th }}$ ed. SAS. Inst. Inc. Cary. N.C. USA.

21. Prescott, G.W. 1982. Algae of the Western Great Lakes Area. Second Edition. Otto Koeltz Science Publishers, Koenigstein.

22. Hustedt, F. 1930. Bacillariophyta (Diatomeae). In: Die Süsswasser - Flora Mitteleuropas. Heft. 10, 2. Aufl. (Pascher, A. Eds), pp. vii +466 
23. Chisti, Y. 2008. Biodiesel from microalgae beats bio-ethanol. Trends in Biotechnol. 26(3): $126-131$.

24. Shen Y, Pei Z, Yuan W, Mao E2009 Effect of nitrogen and extraction method on algae lipid yield. Int. J Agric. Biol. Eng,. 2 (1):51-57

25. Widjaja A. 2009. Lipid production from microalgae as a promising candidate for biodiesel production. Makara, Teknologia 13: 47-51.

26. Converti , A., Casazza, A. A., Ortiz, E. Y., Perego, P. and Borghi, M. D. 2009. Effect of temperature and nitrogen concentration on the growth and lipid content of Nannochoropsis oculata and Chlorella vulgaris for biodiesel production. Chem. Eng. \& Pro. 48 : 1146-1151.
27. Montoya, E. Y. O., Carvalho, J. C. M., Converti, A. 2010. Effect of temperature and nitrogen concentration on the growth and lipid content of Nannochoropsis oculata for biodiesel production. Paper presented at the 10th Symposium Brazil-Japan 2010, the Field grande/MS/08 October 12, 2010.

28. Lv JM, Cheng LH, Xu XH, Zhang L. and Chen H. L. 2010. Enhanced lipid production of Chlorella vulgaris by adjustment of cultivation conditions. Bioresour. Technol. 101(17): 6797-6804.

29. Abd El-Moneim M. R. Afify, Emad A. Shalaby and Sanaa M. M. S. 2010. Enhancement of biodiesel production from different species of algae. Grasas Y Aceites, 61 (4):416422 . 


\section{محاولة لتحفيز انتاج الدهون للايزل الحيوي من الطحالب الدقيقة المعزولة محليا في العراق القيوي من

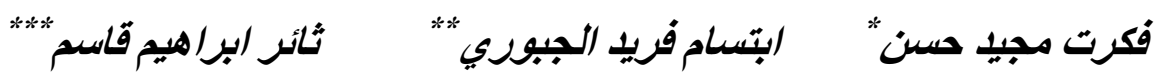

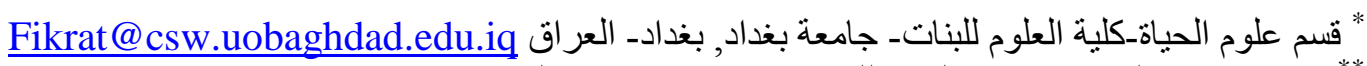

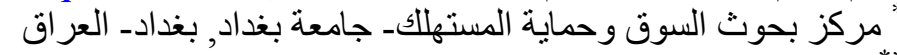

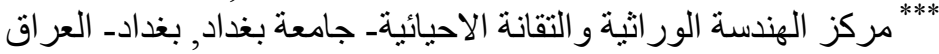

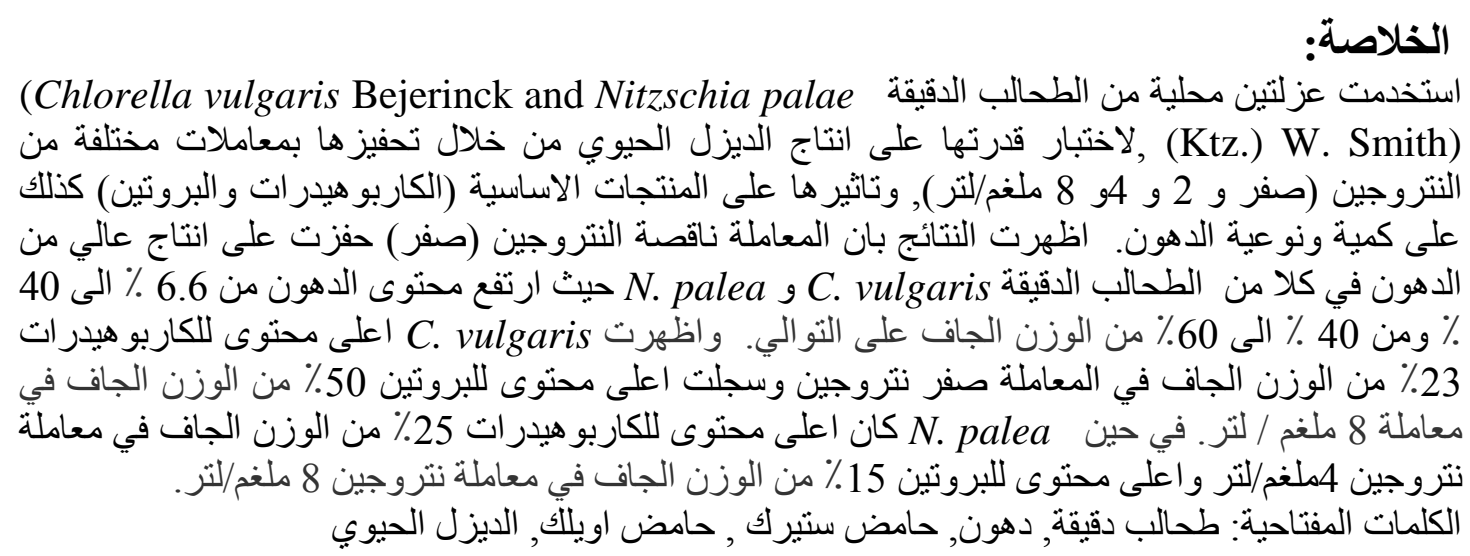

